\title{
on the risks of approaching a philosophical movement outside of philosophy
}

\author{
walter omar kohan ${ }^{1}$ \\ state university of rio de janeiro, brasil \\ david knowles kennedy ${ }^{2}$ \\ montclair state university, united states of america
}

abstract

Biesta states at the beginning of his intervention that he will speak "as an educationalist," outside not only of "philosophical work with children" but "outside of philosophy." What are the implications of these assumptions in terms of "what is philosophy?" and "what is education?" Can we really speak about "philosophical work with children" outside philosophy? What are the consequences of taking this position? From this initial questioning, in this response some other questions are offered to Biesta's presentation: is philosophical work with children about asking better questions or asking questions better, as he states in his presentation? Finally, risks of philosophy for children as presented by Biesta are examined: a) of being reduced to critical thinking, i.e., "to keeping a clear head"; b) that, even extended to creative and caring thinking, it could "stay in the head" and "not touch the soul"; c) that through the building of communities of inquiry in the classroom, we establish a kind of artificial setting where "we end up living in an idea about the world rather than the world". Our response ends with a last reference to Biesta's approach to education in terms of "growing" and existence in terms of a "grown-up way" of being in the world.

keywords: philosophy with children; critical thinking; risks; dogmatic image of thinking

\section{sobre os riscos de se abordar um movimento filosófico fora da filosofia}

resumo

Biesta declara no começo de sua intervenção que ele falará "como um experto educacional" de fora não somente do "trabalho filosófico com crianças" mas também "de fora da filosofia". Quais são as implicações destas suposições em termos de "o que é a filosofia?" e "o que é a educação?". Podemos realmente falar sobre "trabalho filosófico com crianças" de fora da filosofia? Quais são as consequências de se tomar tal posição? A partir deste questionamento inicial, e em sua resposta, algumas outras questões são oferecidas à apresentação de Biesta: o trabalho filosófico com crianças diz respeito a perguntar questões melhores ou a perguntar melhor questões, como ele defende em sua apresentação? Finalmente, os riscos da filosofia para crianças, tal como apresentados por Biesta, são examinados: a) ser reduzida ao pensamento crítico, i.e., a "manter uma cabeça esclarecida"; b) mesmo ela sendo estendida ao pensamento criativo e cuidador, poderia mesmo assim "ficar na cabeça" e "não tocar a alma"; c) que através da criação de comunidades de questionamento na sala de aula, estabeleçamos um tipo de cenário artificial onde "acabamos vivendo em uma ideia sobre o mundo ao invés de no mundo mesmo". A resposta acaba com uma última referência à abordagem de Biesta

\footnotetext{
${ }^{1}$ E-mail: wokohan@gmail.com

${ }^{2}$ E-mail: dkeleutheros@gmail.com
} 
on the risks of approaching a philosophical movement outside philosophy

da educação em termos de "crescimento" e existência em termos de "um jeito adulto" de estar no mundo.

palavras-chave: filosofia com crianças; pensamento crítico; riscos; imagem dogmática do pensamento.

\section{sobre los riesgos de abordar un movimiento filosófico fuera de la filosofía}

resumen

Biesta declara en el inicio de su intervención que hablará como un "experto en educación" que no sólo viene de afuera del campo de la filosofía con niñas y nhiños sino también de la filosofía en general. ¿Cuáles son las implicancias de estos supuestos en términos de lo "qué es la filosofía"? ¿Cuáles son las consecuencias de tomarse tal postura? A partir de este cuestionamiento inicial, y en su respuesta, algunas otra cuestiones son ofrecidas a la presentación de Biesta: el trabajo filosófico con niñas y niños dice respecto al preguntar mejores cuestiones o al preguntar mejor, como él defiende en su presentación? Finalmente, examinamos los riesgos de la filosofía con niñas y niños, tal como son presentados por Biesta: a) ser reducida a pensamiento crítico, i.e., "mantener una cabeza esclarecida"; b) incluso siendo ella extendida al pensamiento creativo y cuidadoso, podría aún así "quedarse en la cabeza" y "no tocar el alma"; c) a través de la creación de comunidades de indagación en el aula podería establecerse un tipo de escenario artificial donde "acabamos viviendo en una idea sobre el mundo mas que en el mundo mismo". Este texto termina con una última referencia al abordaje de Biesta a la educación en términos de "crecimiento" y a la existencia en términos de "una forma adulta" de estar en el mundo.

palabras clave: filosofía con niñas y niños, pensamiento crítico, riesgos, imagen dogmática del pensamiento. 
on the risks of approaching a philosophical movement outside philosophy

Gert Biesta is one of the most prominent names in the contemporary field of philosophy of education. As such, his presence at the last ICPIC Conference in Madrid, July 1st, 2017, was a significant educational and philosophical opportunity to expose an "external" and at the same time reflective and caring voice to different participants of diverse regions of the world committed to the movement of philosophy with children. The main aim of this paper is to foster a space of dialogue opened by this opportunity. Even though Biesta is author of an extended bibliography, where he expands some of the views offered in his PowerPoint presentation, we prefer to concentrate on the latter in order to try to reach at what could be at the heart of his analysis.

Philosophy for children usually generates positive and negative passions-sometimes even indifference--and, more rarely, an intellectual disposition to put into question its assumptions and aims. For this reason, Biesta's intervention was particularly interesting, offering as it did a critical perspective on philosophical work with children in the affirmative sense of the world "critical"--i.e. that of someone who does not merely condemn or praise the endeavor, but offers rich arguments that put it into question, and which help us to think again about what we do under its name. What could be more educational and philosophical than such an opportunity?

The first thing that comes to our attention is the title of Biesta's presentation: "Touching the soul? Education, Philosophy and Children in an Age of Instrumentalism." The leading question contains the word "soul" with its heavy and prominent philosophical implications, and suggests a kind of humanist perspective, which might be confirmed by different elements at the talk itself. The second part of the title affirms a theoretical framework ("education, philosophy and children") and a disapproving perspective on our current educational epoch, considered under the category of instrumentalism. What surprises us here is that almost immediately after 
providing this framework, Biesta states, at the start of his presentation, that he will speak "as an educationalist" outside, not only of "philosophical work with children"-which seems reasonable in terms precisely of his relation to the specific field of philosophy for children--but also "outside of philosophy." How should we take this delimitation of fields and spaces? How can someone set up an intellectual space in the relationships between three fields and then exclude his intervention from one of the three of them? In what sense can a philosophical undertaking--one that has philosophy in its very title, and which identifies itself in terms of the introduction of philosophy in the education of childhood--be approached outside philosophy? Why?

One way of understanding this self-positioning would be to consider Biesta's choice as taking some distance from philosophy as an academic field. In another sense, as many other intellectuals have done, particularly some who have influenced Biesta himself like Foucault, Levinas or Rancière, the refusal to be considered a philosopher (which is not exactly what Biesta claims) might be understood in the sense of an affirmation of a more interdisciplinary or unspecific task, one which crosses the fields of philosophy, education and others as well. For example, a similar perspective is adopted by another prominent contemporary pedagogue, the Belgian Jan Masschelein, who has listed at least two main reasons not to consider his work philosophical, or to in fact ponder himself "out of philosophy": a) from it's Platonic "beginning" forward, philosophy affirms an aristocratic gesture that in itself would be a taming or at least a forgetting of school and a neglecting of its public character: ever since Plato's cave, philosophy and philosophers have promulgated a sort of ethical command--"you must change your life"--that hides the form of educational experience that embodies a disclosure of the world, a making something public, and the discovery of an impotentiality - that is, disclosing ones capacity (KOHAN; MASSCHELEIN, 2015, p. 92-3); b) while philosophy is related to the experience of wonder or stupefaction, education is related to the experience of attraction, and of not being unable (KOHAN; MASSCHELEIN, 2015, p. 93). It is for these reasons that 
Masschelein stresses that his perspective is pedagogical or educational (the difference between the two would deserve another paper) and not philosophical. We wonder if what is hidden in this refusal of Biesta to be placed "inside of philosophy" is some argument close to Masschelein's, or whether there are other reasons as well.

Whatever the reasons might be for Biesta to situate himself outside philosophy, what are the implications of these reasons in terms of the questions "what is philosophy?" and "what is education?" in his intervention? Can we, even in educational terms, speak about "philosophical work with children" outside philosophy? What are the educational implications of this position? We have argued (KOHAN \& MASSCHELEIN, 2015) that his reading of Plato's beginning is not the only beginning of philosophy, even in the Socratic-Platonic context, and if we follow Foucault's reading of this beginning we find a line of thinking in which philosophy, in its Socratic beginnings, has to do with the two points offered by J. Masschelein as specifically pedagogical - that is, a disclosure of the world and the discovery of an impotentiality. On this understanding philosophy, which is closer to a way of living than to a form of knowledge (FOUCAULT, 2001), cannot but be educational, and education cannot but be philosophical. Something quite similar is affirmed by Matthew Lipman in the book that first presented philosophy for children to the broad academic community: "all true philosophy is educational and all true education is philosophical." (Lipman, 1988, p. 43). In any case, we wonder what is lost when education is considered as outside of philosophy (or as educationalists and not philosophers, in the sense suggested above). And the same argument could be reversed: what is lost when philosophy is thought of as outside education, or when philosophers consider themselves other than educationalists?

From this broad opening question, we offer a few interrogations of some other affirmations found in Biesta's presentation: is philosophical work with children, as he affirms, about asking better questions or asking questions better? Are philosophy for children' more dangerous risks the ones Biesta presents ("to keep a clear head") or 
are these risks so alarming precisely when philosophy is put aside? Finally, we will question the manner and terminology through which Biesta establishes what he calls the primary educational question: "arousing the desire in another human being for wanting to exist in the world in a grown-up way." Is philosophy for children'--and more broadly, any educational philosophy's educational aspiration--about "arousing desire" in others? Is it about human beings? Is it about existing in the world in a given way and more precisely in a grown-up way?

While asserting philosophy for children's importance in contemporary curriculum, Biesta affirms its importance in terms of "not filling children with answers but making space for asking questions, asking better questions, asking questions better." The topic of connecting children--and philosophy--with questions is addressed extensively in the philosophy for children literature; in fact it is a major theme (WEBER; WOLF, 2017). There are three aspects, however, that command our attention in Biesta's way of addressing the topic that might be said to share a space with P4C literature: the first one is the opposition between answers and questions; the second, a sort of moral qualification of questions ("better" and "worse"); and a third one that translates this moral qualification from the questions themselves to the process of asking questions - that is, from asking better questions to asking questions better.

Biesta might agree in condemning the kind of false opposition that the question-answer carries, particularly in terms of their educational value, especially if we consider that education is not mainly about offering answers or questions but about fostering a given disposition to relate oneself to questions and answers. A constructivist teacher--who is far from Biesta's model of the good teacher (whatever this might be)--might agree with the critique of the overemphasis of questions over answers. What seems clear is that it is less interesting to consider education as offering this or that than as offering a certain opportunity to relate to this or that in 
ways that could be defined, from different perspectives, as educationally relevant or meaningful.

What seems more problematic in Biesta's presentation is the moralization of education contained in the notion of the "better"-- a moralization that is not at all absent in philosophy for children. Even Lipman described its task in analogous terms as fostering "good thinking", "better thinking" or "higher order thinking" in children. This form of moralization is an example of what G. Deleuze called the dogmatic, moral or naturalized image of thinking (1994). It is a moral image because only the moral is capable of convincing us of the good nature of thinking and of the good will of the thinker: in this paradigm only the good can found the affinity between thinking and true (DELEUZE, 1988, p. 225). In more simple terms we could say that underlying this image of thinking it is the idea that only if we think well we are going to reach the truth. In Deleuzian terms it is particularly significant that philosophy for children as an enterprise that describes itself as "teaching to think," "thinking about thinking" and other similar ways presuppose a moral and unquestioned image of what it means to think and of what constitutes the "good thinker." Biesta seems to be sharing this image in his presentation, even though he would define a "good thinker" very differently from most philosophy for children educators.

There are two other aspects we would like to question related to Biesta's ways of posing the aims of philosophy for children in relation to questions. One is probably connected to the absence of a philosophical perspective. In its broadest sense, philosophy is not about content or knowledge but about a relationship to it. In terms of questions, philosophy is not allocated in questions themselves but in questioning: in our relationship to questions; in what we do with questions or what we let questions do with us. This means that philosophy is relational, and for that reason it is located neither in answers nor in questions. Furthermore, this relational questioning could be guided more by answers than by questions. It could also be said 
that philosophy is located in answering--in a given relationship to answers. Thus, we might affirm that philosophy for children is related more to fostering a sort of questioning/answering being in the world than to teaching students how to make philosophical questions/answers. This way of understanding educational workand, more specifically, philosophy for children--might also help to avoid the kind of instrumentalism condemned by Biesta, to which philosophy for children itself is also frequently prone. It is technically simple or easy to learn how to do "philosophical questions" once we define the criteria that those questions should satisfy, and "good students" learn quickly to produce them. On the other hand, to put one's thinking, one's life, one's self into question is not so easy: it is technically impossible to establish criteria for what it means to live life philosophically outside of a given situated life.

Biesta identifies at least two main risks associated with philosophy for children in our times: a) being reduced to critical thinking, whereby it is understood merely as a useful skill for dealing within our capitalist global world; b) even extended to creative and caring thinking, it could still "stay in the head" and "not touch the soul." Biesta is probably thinking of some versions of philosophy for children, found mainly in Anglo-Saxon contexts, that are actually over intellectualized. In these versions it really does have the look of an instrumental tool ("strongly conceptual and verbal ... working towards logical conclusions and representing a particular 'slice' of the analytical-logical philosophical tradition") that could well serve the reproduction of the neocapitalist order under the guise of "high order, multidimensional or complex thinking." On the other hand, there are many P4C contexts in which critical thinking is a less important dimension of philosophical experiences with children, nor is thinking considered as a set of tools or skills that could be fostered in any of the senses mentioned above. We are thinking particularly of some Latin American experiences like the one in Duque de Caxias, Brazil, where we do exercises related more to forms of life than to thinking skills. We do not consider thinking to be a set of 
tools, but rather a sensitive encounter with what provokes us to question our actual way of being in the world. For example, Juliana, an 11 year old student in a public school in Duque de Caxias described in this way what philosophy is about:

philosophy for me is a different way of looking at things. Be able to think on what they are, where they come from. Philosophy is thinking and dialogue, it's a conversation that makes us think more and more in the "why?", the "what is it?". This is what philosophy is for me, in my life. Philosophy could be summarized in thoughts and questions. Philosophy certainly changed my life. Now I am more interested in thinking in different things... I am more patient, more calm and am capable to talk with other people without being ashamed, without thinking they will laugh at me. (Juliana Muniz da Silva Rodrigues. In: KOHAN; OLARIETA, 2012, p. 168)

Whatever analysis might be offered of this testimony, it is clear that philosophy is not a technique but something that affects a way of being ("Philosophy certainly changed my life... I am more patient, more calm and am capable of..."). While philosophy is in fact connected to thinking ("Philosophy is thinking and dialogue"), it is more connected to a broad form of sensitivity ("philosophy for me is a different way of looking at things...") than to a mere intellectual activity. It affects the way we relate to things and people in the world. This seems to be close to what Biesta claims as "the I who is in question," or even to "a subject who is being called into the world." It is also, as Masschelein would phrase it, about a disclosing of ones own capacities: "I am capable to talk with other people without being ashamed...."

In another dimension of analysis, Biesta seems to be assuming a humanistic, dualistic perspective that does not consider the post-human developments in philosophy for children (MURRIS, 2011), where precisely the kind of approach he is affirming is questioned and problematized. As post-human perspectives are addressed specifically in this Dossier we are not going to take them up extensively here, but simply note how they reveal philosophy for children as a living movement sensitive to academic debate; and that Biesta's intervention also contains elements that might be closer to these perspectives; especially when he affirms a form of 
education that it is "not child-centered, not curriculum-centered also not competencecentered, or skills-centered but world-centered".

Another significant risk associated with the practice of P4C that is addressed in Biesta's presentation is that through the building of communities of inquiry in the classroom we establish a kind of artificial setting in which "we end up living in an idea about the world rather than the world." As we see it, this is a very relevant and crucial risk. Even Lipman's philosophical novels might be understood as feeding this kind of artificial idealized context with characters who enact an ideal world, with idealized relationships in ideal institutions, very far in terms of the practices of desire and power from the actual world we live in. We think that this risk should be seriously taken by philosophy for children practitioners; and it is one of the reasons some of us prefer not to work with Lipman's curriculum in our philosophical experience with children.

Finally, we will touch briefly on an issue that we are aware many other respondents will deepen in this debate: Biesta's approach to education in terms of "growing," and to existence in terms of a "grown up way" of being in the world. It is true that Biesta does not identify this growing up with an age or chronology. Rather, it has to do with a "subject ...not in the center of the world ... not the outcome of a developmental trajectory but a non-ego-logical way of being in the world...: putting one's desires 'in perspective.'" For Biesta it is not that children are necessarily infantile and adults always grown-ups, as he clarified in his responses to his talk, but that there are forms of infantile existence and of grown- up existence as well. What makes the difference is an ego-logical existence versus a world-centered existence. And education would provide, through interruption, suspension and sustenance, the path along which to move oneself from the center of the world and to put the world in the center - that is, to "desire the desirable." So the problem seems to lie in Biesta's nomenclature of this movement from infantile to grown-up existence, which could only be meaningful if infantilism is associated with egocentrism. On what could such 
a nomenclature be based if not a shared assumption with dominant developmental theory about a first period of egocentric existence in human life? If there is no ageism underlying this terminology, why should he maintain it? In what non-ageist sense does "grown-up" meaningfully describe a world-centered existence, one that desires the desirable? And so, not unexpectedly, we finish this commentary on Biesta's questioning with further questions.

\section{references}

DELEUZE, G. Difference and Repetition. New York: Columbia University Press, 21994.FOUCAULT, M. The Hermeneutics of the Subject. Lectures at the College of France 19812. New York: Palgrave, 2001.

KOHAN, W. \& OLARIETA, B. (eds.) A escolar pública aposta no pensamento. Belo Horizonte: Autêntica, 2012.

KOHAN, W. \& MASSCHELEIN, J. “The pedagogue and/or the philosopher? An exercise in thinking together". In: KOHAN, W. Childhood, education and Philosophy. New ideas for an old relationship. New York: Routledge, 2015, p. 90-113.

LIPMAN, M. (1988). Philosophy Goes to School, Tampa: Tampa University Press, 1988.

MURRIS, K. The Posthuman child. New York: Routledge, 2011.

WEBER, B. \& WOLF, A. "Questioning the question: a hermeneutical perspective on the "art of questioning" in a community of philosophical Inquiry". In: Gregory, M; HAYNES, J. \& MURRIS, K. (eds.) The Routledge International Handbook in Philosophy for children. New York: Routledge, 2017, p. 74-82.

received in: 12.08 .2017

accepted in: 08.09.2017 